\title{
Upland rice seedling performance promoted by multifunctional microorganisms
}

\section{Desempenho de plântulas de arroz de terras altas promovido por microrganismos multifuncionais}

\author{
João Pedro Tavares Fernandes ${ }^{1 *}$; Adriano Stephan Nascente ${ }^{2}$; \\ Marta Cristina Corsi de Filippi²; Mariana Aguiar Silva ${ }^{3}$
}

\section{Highlights}

Multifunctional microorganisms (MM) can stimulate the root development of crops.

We studied the effects of six MM on the roots of upland rice.

The MM Azospirillum sp. provided the best upland rice root development.

\begin{abstract}
Multifunctional microorganisms can contribute to the development of plant root systems and positively affect the grain yield of crops. However, studies of the use of these microorganisms to benefit root development in rice plants are scarce. The objective of this study was to determine the effect of rhizobacterial inoculation of the seeds on the root development of upland rice seedlings. The experiment was carried out in the agricultural microbiology laboratory of Embrapa Rice and Beans, and we adopted a completely randomized design with eight replications. The treatments consisted of the inoculation of rice seeds with the rhizobacteria 1. Pseudomonas fluorescens (BRM 32111), 2. Burkholderia pyrrocinia (BRM 32113), 3. Serratia sp. (BRM 32114), 4. Bacillus sp. (1301), 5. Azospirillum brasilense (Ab-V5), 6. Azospirillum sp. (1381), and a 7. control treatment (without microorganisms). Treatment using the microorganism Azospirillum sp. (1381) provided the longest roots, greatest root volume and highest total dry mass of roots, at $86.34,111.53$ and $29.41 \%$, respectively, significantly superior to the control treatment. In addition, treatments Ab-V5 and Bacillus sp. (1301) resulted in a root diameter of 13.81 and $13.06 \%$, respectively, larger than that of the control treatment. The use of these multifunctional microorganisms was efficient for promoting the root development of rice seedlings.
\end{abstract}

Key words: Oryza sativa. Rhizobacteria. Root development. Sustainability.

1 Discente do Curso de Doutorado do Programa de Pós-Graduação em Produção Vegetal, PGAPV, Universidade Federal do Paraná, UFPR, Campus Juvevê, Curitiba, PR, Brasil. E-mail: joaopedroagronomo@gmail.com

2 Pesquisadores, Drs., Empresa Brasileira de Pesquisa Agropecuária, EMBRAPA Arroz e Feijão, Santo Antônio de Goiás, GO, Brasil. E-mail: adriano.nascente@embrapa.br; cristina.filippi@embrapa.br

3 Discente do Curso de Doutorado do Programa de Pós-Graduação em Produção Vegetal, PPGA, Universidade Federal de Goiás, UFG, Campus Samambaia, Goiânia, GO, Brasil. E-mail: marianaaguiar23@hotmail.com

* Author for correspondence

Received: Sept. 17, 2019 - Approved: June 10, 2020 


\section{Resumo}

Microrganismos multifuncionais podem contribuir para o desenvolvimento do sistema radicular de plantas afetando positivamente a produtividade de grãos das culturas. Objetivou-se determinar o efeito da inoculação de rizobactérias em sementes no desenvolvimento radicular de plântulas do arroz de terras altas. O experimento foi conduzido no laboratório de microbiologia agrícola da Embrapa Arroz e Feijão, e adotando delineamento experimental inteiramente casualizado, com oito repetições. Os tratamentos consistiram da inoculação em sementes de arroz com as rizobactérias 1. Pseudomonas fluorescens (BRM 32111), 2. Burkholderia pyrrocinia (BRM 32113), 3. Serratia sp. (BRM 32114), 4. Bacillus sp. (1301), 5. Azospirillum brasilense (Ab-V5), 6. Azospirillum sp. (1381), e 7. tratamento controle (sem microrganismo). O tratamento com a utilização do microrganismo Azospirillum sp. (1381) proporcionou maior comprimento radicular, volume de raízes e massa seca total de raízes, sendo respectivamente, 86,34, 111,53 e 29,41\%, superior ao tratamento controle e diferiu significativamente. Além disso, os tratamentos Ab-V5 e Bacillus sp. (1301) proporcionaram maior diâmetro radicular nas plantas de arroz, sendo 13,81 e 13,06 \% respectivamente superior ao tratamento controle. $\mathrm{O}$ uso destes microrganismos multifuncionais foi eficiente em sua capacidade de proporcionar incrementos no desenvolvimento radicular de plântulas de arroz.

Palavras-chave: Oryza sativa. Rizobactérias. Desenvolvimento radicular. Sustentabilidade.

Considering the prospect of population growth and, consequently, the greater demand for food, it is essential to increase the production and productivity of agricultural crops such as upland rice in a sustainable way (Nascente et al., 2017). However, increasing the productivity of upland rice is a challenge considering the biotic and abiotic stresses, such as the occurrence of diseases, prolonged periods of summer, and nutritional deficiencies, as well as problems with the initial grubbing and growth of the plant in no-till areas (Filippi et al., 2011). In this context, the use of multifunctional microorganisms in an upland rice cultivation system represents a management option whose purpose is to promote the growth of the plants through promoting greater development of the root system, increasing the absorption of nutrients, and increasing the efficiency of gas exchange and, consequently, increasing phytomass production and grain productivity (Nascente et al., 2017).
Among the multifunctional microorganismsthatcancontributetoimproving the performance of plants, rhizobacteria stand out. They are microorganisms that colonize the roots and can promote plant growth (KokalisBurelle, Kloepper, \& Reddy, 2006; Sousa, Nascente, \& Filippi, 2019; Kloepper \& Schroth, 1978) by performing beneficial activities such as the synthesis of hormones (auxin, gibberellins and cytokinins), which contribute to the solubilization of minerals, in addition to synthesizing enzymes related to the resistance of plants to pests and diseases (Bhattacharyya \& Jha, 2012).

Some of the most important multifunctional microorganism genera are Azospirillum, Burkholderia, Pseudomonas, Bacillus, and Serratia. These microorganisms have already been studied in association with several agricultural crops, and their beneficial effects on production and productivity components have been proven (Matoso et 
al., 2020). However, there are still several questions to be answered due to the great biodiversity of multifunctional microorganisms and the complexity of their mechanisms of action (Matoso et al., 2020). As well, there are few studies related to the use of multifunctional microorganisms to promote the root development of rice plants. Thus, the present work hypothesized that the microbiolization of upland rice seeds with multifunctional microorganisms would promote greater root development compared to that of untreated seeds. Thus, this study aimed to determine the effect of inoculation of seeds with rhizobacteria on the root development of upland rice seedlings.

The experiment was conducted in the agricultural microbiology laboratory, in November 2019, at Fazenda Capivara, headquarters of Embrapa Arroz e Feijão, located in the municipality of Santo Antônio de Goiás, Goiás, Brazil. The experimental design was completely randomized with seven treatments and eight replications. The treatments consisted of the microbiolization of the seeds (a process that puts the seed in contact with the rhizobacteria solution to be tested) of rice with the multifunctional microorganisms Pseudomonas fluorescens (BRM 32111), Burkholderia pyrrocinia (BRM 32113), Serratia sp. (BRM 32114), Azospirillum sp. (1381), Azospirillum brasilense (Ab-V5) and Bacillus sp. (1301), and the control treatment (without microorganisms). The multifunctional microorganisms used in this experiment were deposited in the collection of microorganisms of agricultural importance of Embrapa Rice and Beans (CNPAF). The biochemical characteristics and taxonomic classification of the multifunctional microorganisms used in this research are available at Nascente et al. (2017).
Isolates of cultures of themultifunctional microorganisms grown on a solid medium (nutrient agar) were used to prepare the suspensions of each microorganism, and the suspensions were prepared in liquid medium 523 (nutrient broth) (Kado \& Heskett, 1970) in a shaking incubator for 24 hours at $28{ }^{\circ} \mathrm{C}$. The cell suspension concentration of the bacterial isolates was adjusted using a spectrophotometer to $\mathrm{A} 540=0.5$, which corresponds to $1 \times 10^{8}$ colony-forming units (CFU) per $\mathrm{mL}$. Prior to the microbiolization, the seeds were disinfected by immersing them in $70 \%$ alcohol for one minute and then in $0.05 \%$ sodium hypochlorite for the same time, followed by drying at room temperature at $29{ }^{\circ} \mathrm{C}$. Microbiolization occurred with the immersion of the seeds in the rhizobacterial cell suspension, and for the control treatment, with the immersion of the seeds in distilled water, for 24 hours at a temperature of $25{ }^{\circ} \mathrm{C}$, under constant agitation, following the proposed methodology of Filippi et al. (2011). For the vigor test of the upland rice seeds, before sowing in a solid medium (agar-water), the vigor and germination of the seeds were analyzed following the methodology of Ministério da Agricultura, Pecuária e Abastecimento [MAPA] (2009), obtaining the values of 98 and $100 \%$, respectively.

Each plot or experimental unit was composed of a rice seed cultivar BRS A501 $\mathrm{CL}$, placed to germinate in a $50 \mathrm{~mL}$ volume test tube containing $15 \mathrm{~mL}$ of agar-water medium $(0.8 \mathrm{~m} / \mathrm{v})$. The tubes were placed in a germination chamber at $28{ }^{\circ} \mathrm{C}$, with a 12-hour photoperiod, and were removed ten days after sowing following the methodology proposed by Sperandio et al. (2017). The seedlings were removed from the test tubes, photographed with a digital camera and image processing 
was performed. The images obtained were analyzed using WinRHIZO 2012 software, Regent Instruments, Inc. Quebec city, QC, Canada, (Arsenault, Pouleur, Messier, \& Guay, 1996). With the software, these parameters were determined: Total Root Length (CompR, $\mathrm{cm})$, Root Diameter (DiamR, $\mathrm{mm})$, and Root Volume $\left(\right.$ VolR, $\left.\mathrm{cm}^{3}\right)$. After recording the images, the dry biomass of the rice seedlings was determined after dehydration in a forced air chamber at $65^{\circ} \mathrm{C}$ until a constant mass by checking the values on a precision scale.

Regarding statistical analysis, first, the normality of errors (Shapiro-Wilk test) and the homogeneity of variance (Bartlett test) were determined. Then, the data were subjected to analysis of variance and, when significance was detected, the means were compared using the Tukey test ( $p \leq 0.05)$. The SASM-Agri statistical package was used for data processing (Canteri, Althaus, Virgens, Giglioti \& Godoy, 2001). In addition, multivariate principal component analysis was performed to describe the correlations between the response variables (CompR (cm), DiamR (mm), VolR $\left(\mathrm{cm}^{3}\right)$ and MassaS (g)) and the microorganism isolates. The main components (PCs) were loaded with response variables when the result of the correlation test produced $r \geq 0.50$. The biplots (two-dimensional graph) correlated the isolated microorganisms and the response variables, and for this purpose, the package "FactoExtra" (Kassambara, 2015) was used on the platform $\mathrm{R}$.

Compared to the control treatment, the treatments with the multifunctional microorganisms provided higher values in the different parameters evaluated (Table 1). The roots of the rice seedlings treated with Azospirillum sp. (1381) were $86.34 \%$ longer than those of the control treatment. A similar result was found in an experiment conducted by Sousa, Nascente and Filippi (2019), in which microbiolized seeds with rhizobacteria developed longer roots in the irrigated rice seedlings compared to those of control treatment seedlings. In this context, it should be noted that multifunctional microorganisms can increase the production of phytohormones, providing better root development and exerting beneficial effects on plants, such as more water and mineral absorption, which significantly affects the production of biomass and crop productivity (Nascente et al., 2017). 
Table 1

Total root length (LengthR), root diameter (DiamR), root volume (VoIR, cm3) and dry root mass (MassS) of upland rice seedlings cultivar BRS A501 CL as a function of treatment with microorganisms. Evaluation performed 10 days after rice sowing

\begin{tabular}{lcccc} 
& LengthR & DiamR & VolR & MassS \\
\cline { 2 - 5 } Treatments & $(\mathrm{cm})$ & $(\mathrm{mm})$ & $\left(\mathrm{cm}^{3}\right)$ & $(\mathrm{g})$ \\
\hline Burkholderia pyrrocinia (BRM 32113) & $25.09 \mathrm{~b}$ & $0.40 \mathrm{a}$ & $0.033 \mathrm{~b}$ & $0.0208 \mathrm{ab}$ \\
Pseudomonas fluorescens (BRM3211) & $23.73 \mathrm{~b}$ & $0.43 \mathrm{a}$ & $0.036 \mathrm{~b}$ & $0.0214 \mathrm{ab}$ \\
Serratia sp. (BRM32114) & $23.27 \mathrm{~b}$ & $0.43 \mathrm{a}$ & $0.035 \mathrm{~b}$ & $0.0201 \mathrm{ab}$ \\
Bacillus sp. (1301) & $25.02 \mathrm{~b}$ & $0.45 \mathrm{a}$ & $0.038 \mathrm{~b}$ & $0.0188 \mathrm{ab}$ \\
Azospirillum brasilense (Ab-V5) & $25.04 \mathrm{~b}$ & $0.45 \mathrm{a}$ & $0.043 \mathrm{ab}$ & $0.0198 \mathrm{ab}$ \\
Azospirillum sp. (1381) & $40.68 \mathrm{a}$ & $0.41 \mathrm{a}$ & $0.055 \mathrm{a}$ & $0.0222 \mathrm{a}$ \\
Control & $21.83 \mathrm{~b}$ & $0.39 \mathrm{a}$ & $0.028 \mathrm{~b}$ & $0.0174 \mathrm{~b}$ \\
CV (\%) & 20.37 & 11.31 & 19.77 & 15.19 \\
$\sigma$ & 6.42 & 0.022 & 0.01 & 0.0016
\end{tabular}

* Averages followed by the same letter do not differ by the Tukey test $(p \leq 0,05)$.

The highest values for the root diameter (DiamR, $\mathrm{mm}$ ) of the upland rice seedlings was obtained with the treatments Azospirillum brasilense (Ab-V5) and Bacillus sp. (1301), which were 13.81 and $13.06 \%$, respectively, higher than that of the control treatment but not significantly different from that of the control treatment (Table 1). Saharan (2011) found that species of Bacillus sp. contributed to the improvement of different root parameters and that inoculation with isolates producing EIA increased the absorption of $N, P, K, C a$ and $\mathrm{Mg}$, promoting the growth of sweet potatoes and the rooting and dry matter of eucalyptus seedlings. In another study, it was found that multifunctional microorganisms of the genus Bacillus sp. and Azospirillum brasilense (AbV5) provided root increments of flooded rice seedlings in relation to the control treatment (without inoculation) (Sousa, Nascente, \& Filippi, 2019). These results, as well as those observed in the present study, demonstrate the ability of multifunctional microorganisms to enhance the development of the upland rice seedling root system.

We observed that treatment with Azospirillum sp. (1381), in addition to greater root length, also led to a significantly greater volume of roots and a greater increase in grams of dry root mass, at $111.53 \%$ and $29.41 \%$, respectively, higher than those of the control treatment (Table 1). The large increase observed in the parameters evaluated can be explained by the enhanced production of phytohormones by the microorganisms since treatments containing rhizobacteria result in greater root development compared to that of the control treatment (without using microorganisms) (Chagas, Chagas, Carvalho, Miller, \& Colonia, 2015). Hungria (2011), working with soybean and common bean crops, also reported that bacteria of the genus Azospirillum could provide several stimuli for the growth of plants, in addition to biological $\mathrm{N}$ fixation, for the production of plant hormones such as 
auxins, gibberellins and cytokinins, phosphate solubilization, greater root development, increases in chlorophyll content and stomatal conductance. In addition, Correia et al. (2019) found that supplying half a dose of mineral $\mathrm{N}$ in combination with leaf inoculation of an isolate of the genus Azospirillum at a dose of $300 \mathrm{~mL}$ ha $^{-1}$ induced significant increases in wheat crop productivity.

Regarding the analysis of the main components, we found that the variability of

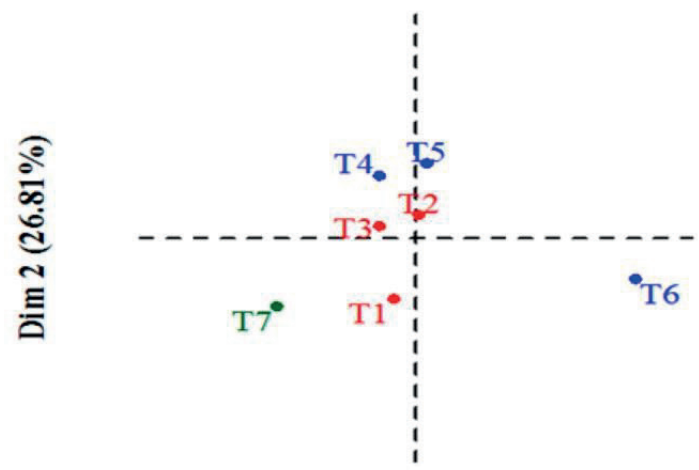

Dim $1(61.58 \%)$

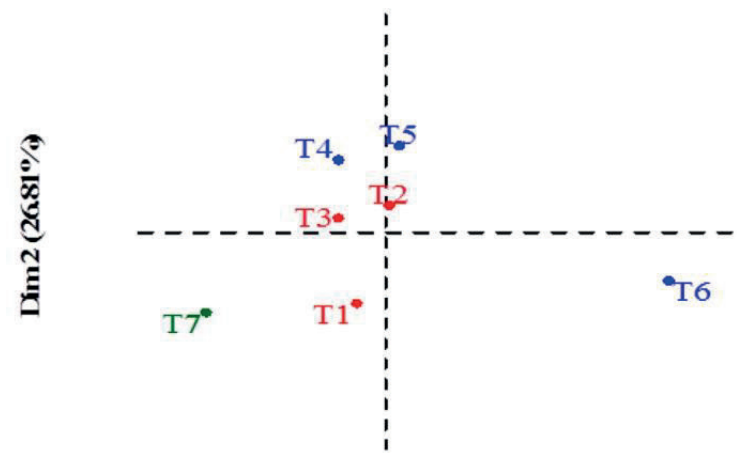

Dim $1(61.58 \%)$ treatments with isolated microorganisms in the components of CompR (cm), DiamR (mm), VolR $\left(\mathrm{cm}^{3}\right)$ and MassaS $(\mathrm{g})$ were better described by two main components (PCs), representing $88 \%$ of the data variation, that is, PC1 (61.58\%) and PC2 (26.81\%) (Figure 1). The factor map (biplot) shows groups of variables (arrows) denoting positive and negative correlations with each main component (PC), with the length of the arrow indicating the magnitude of each response for each PC (Figure 1).

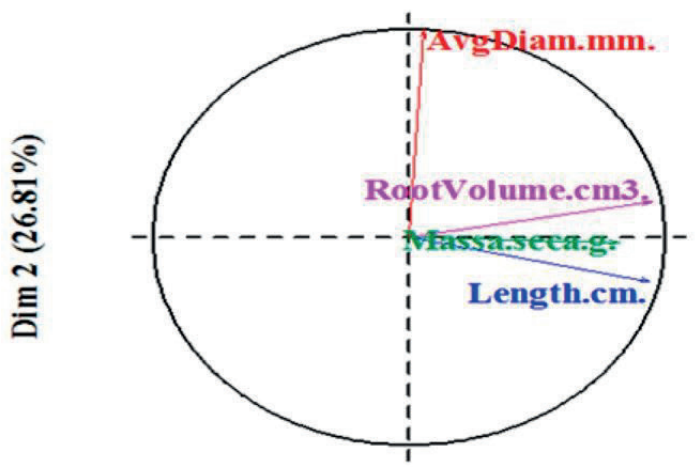

Dim $1(61.58 \%)$

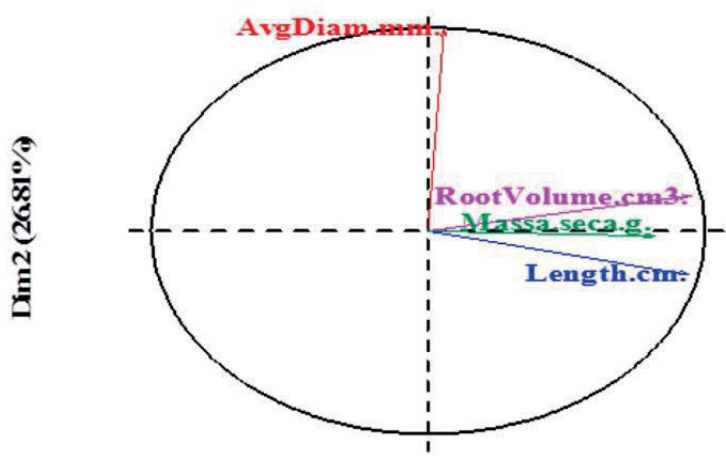

Dim $1(61.58 \%)$

Figure 1. Principal component analysis (PCA) PCA1 X PCA2, explaining correlations between the variables evaluated and seven treatments with isolated multifunctional microorganisms and control (without microorganism). Two main components (PCs) accounted for $88 \%$ of the data variation. The treatments were: 1. Pseudomonas fluorescens (BRM 32111), 2. Burkholderia pyrrocinia (BRM 32113), 3. Serratia sp. (BRM 32114), 4. Bacillus sp. (1301), 5. Azospirillum brasilense (Ab-V5), 6. Azospirillum sp. (1381) and 7. control treatment (without microorganism). 
Regarding the contributions of variables to the main components, it appears that the variables correlated with $\mathrm{PC} 1$ and $\mathrm{PC} 2$ were the most important for explaining the variability in the data set. Length.cm, RootVolume. $\mathrm{cm}^{3}$. and Massa.seca.g. had the greatest contributions to the main components. In addition, these contributions are expressed in \% of the variables in the component projection, being, Length.cm. with Dim.1 36.02\%, RootVolume. cm3. with Dim.1 37\%, Massa.seca.g. with Dim. 1 27\% and AvgDiam.mm. with Dim.2 93\%. The contribution in \% of the treatments in the projection of the components emphasizes treatment 6. Azospirillum sp. (1381) with Dim.1 $68 \%$. This can be explained by the results of different authors who showed greater plant development due to the use of multifunctional microorganisms and cited hormone production as one of the possible reasons for this greater development (Sperandio et al., 2017; Nascente et al., 2017; Sousa et al., 2019). Phytohormones act in the meristematic regions of plants, promoting cell growth and elongation, and consequently greater absorption of water and minerals, resulting in more vigorous and productive plants (Nascente et al., 2017). This greater root development was observed in the images of the root system of rice seedlings in treatments with the use of multifunctional microorganisms compared to the control treatment (Figure 2). 


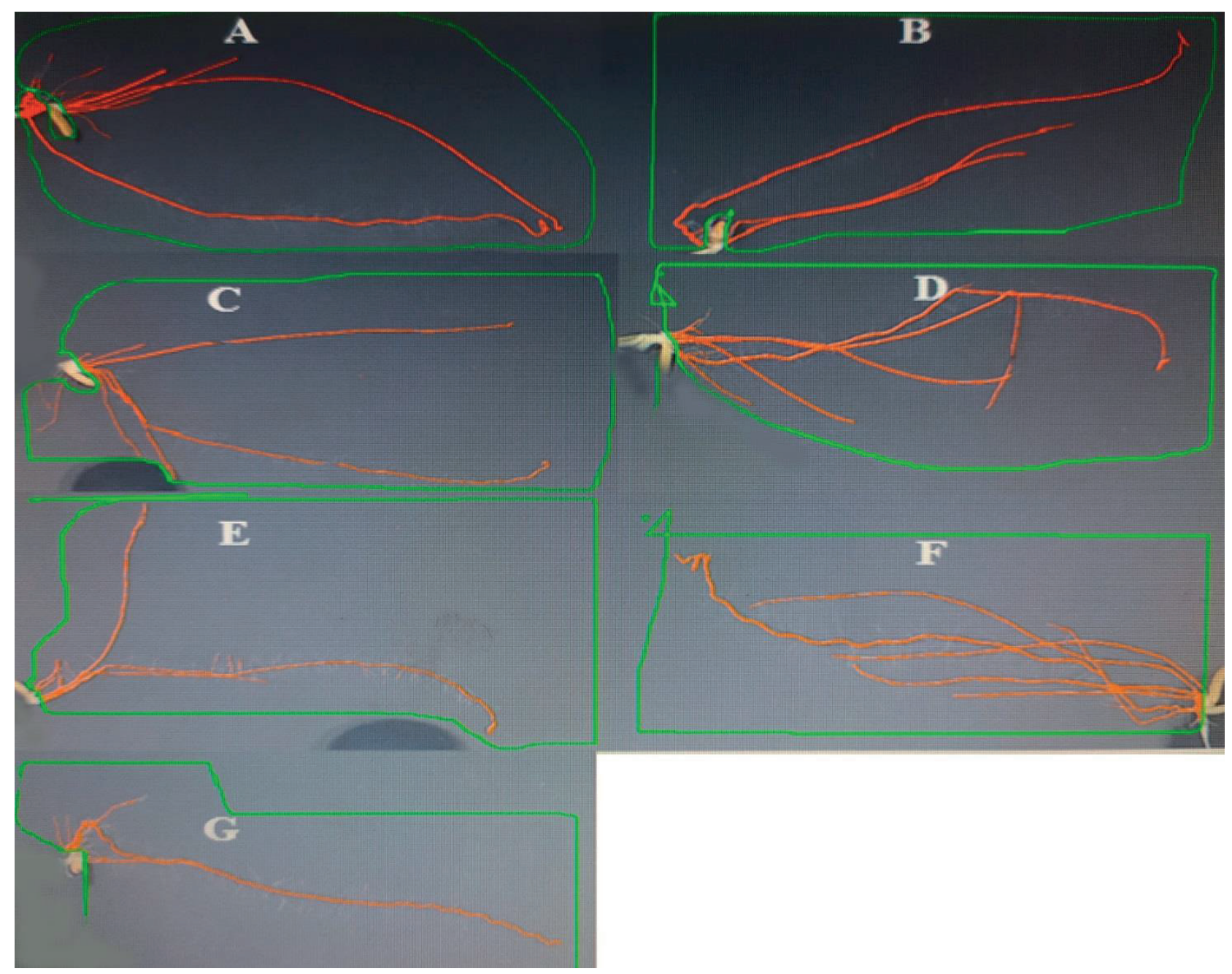

Figure 2. Root system of upland rice seedlings submitted to microbiolization with microorganisms A. Burkholderia pyrrocinia (BRM 32113), B. Pseudomonas fluorescens (BRM32111), C. Serratia sp. (BRM32114), D. Bacillus sp. (1301), E. Azospirillum brasilense (Ab-V5), F. Azospirillum sp. (1381) and G. Control (Without microbiolization). The rice seedlings were photographed ten days after sowing with a digital photographic camera; the images were analyzed using the software WhinRHIZO 2012.

The treatment of upland rice seeds with Azospirillum sp. (1381) provided the highest values in the root system of the seedlings of the culture in all parameters evaluated except for the parameter root diameter (Table 1). From the information obtained from the images of the root system, the greatest development was observed when the seeds were treated with
Azospirillum sp. (1381) compared to the control treatment (Figure 2). According to Moreira, Silva, Nóbrega, \& Carvalho (2010), cultivating upland rice plants with seeds inoculated with Azospirillum sp. showed greater increases in the production of phytohormone 3-indolacetic acid (AIA) as well as greater production of fresh shoots. Thus, the greater production of AIA is 
influenced by the microorganism Azospirillum sp. In addition, this finding may explain the better performance of the root system of upland rice seedlings compared to control treatment plants.

The upland rice seedlings treated with multifunctional microorganisms showed increments in all parameters evaluated in the root system (Total Root Length (CompR, cm), Root Diameter (DiamR, mm), Root Volume (VoIR, $\left.\mathrm{cm}^{3}\right)$ ) in comparison with the control treatment. However, the microorganism Azospirillum sp. (1381) provided higher values in the parameters of Total Root Length (CompR, cm), Root Volume (VolR, cm3) and dry root mass (MassaS, g) in upland rice seedlings at 86.34 111,53 and $29.41 \%$ higher compared to the control treatment.

\section{References}

Arsenault J.-L., Pouleur , S., Messier, C., \& Guay, R. (1995). WinRHIZO, a root-measuring system with a unique overlap correction method. HortScience, 30(4), 906. doi: 10.21273/HORTSCI.30.4.906D

Bhattacharyya, P. N., \& Jha, D. K. (2012). Plant growth promoting rhizobacteria (PGRP): emergence in agriculture. World Journal of Microbiology and Biotechnology, 28(4), 1327-1350. doi: 10.1007/s112 74-0110979-9

Canteri, M. G., Althaus, R. A., Virgens, J. S. F., Giglioti, E. A., \& Godoy, C. V. (2001). SASMAgri: Sistema para análise e separação de médias em experimentos agrícolas pelos métodos Scoft-Knott, Tukey e Duncan. Revista Brasileira de Agrocomputação, 1(2), 18-24.
Chagas, L. F. B., Chagas, A. F., Jr., Carvalho, M. R. de, Miller, L. de O., \& Colonia, B. S. O. (2015). Evaluation of the phosphate solubilization potential of Trichoderma strains (Trichoplus JCO) and effects on rice biomass. Journal of Soil Science and Plant Nutrition, 15(3), 794-804. doi: 10. 4067/S0 718-95162015005000054

Correia, L. V., Felber, P. H., Pereira, L. C., Braccini, A. L., Carvalho, D. U., Cruz, M. A. da, \& Osipi, E. A. F. (2019). Inoculation of wheat with Azospirillum spp.: a comparison between foliar and in-furrow applications. Journal of Agricultural Science; 12(1), 194-199. doi: 10.5539/jas.v12n1p194

Filippi, M. C. C. de, Silva, G. B., Silva-Lobo, V. L., Côrtes, M. V. C. B., Moraes, A. J. G., \& Prabhu, A. S. (2011). Leaf blast (Magnaporthe oryzae) suppression and growth promotion by rhizobacteria on aerobic rice in Brazil. Biological Control, 58(2), 160-166. doi: 10.1016/j. biocontrol.2011.04.016

Hungria, M. (2011). Inoculação com Azospirillum brasiliense: inovação em rendimento a baixo custo. Londrina: EMBRAPA Soja.

Kado, C. J., \& Heskett, M. G. (1970). Selective media for isolation of Agrobacterium, Corynebacterium, Erwinia, Pseudomonas and Xanthomonas. Phytopathology, 60(6), 969-976. doi: 10.1094/phyto-60-969

Kassambara, A. (2015). Factoextra: extract and visualize the results of multivariate data analyses. R Package Version 1.0.3. Recovered from https://rpkgs.datanovia. com/factoextra/index.html

Kloepper, J. W., \& Schroth, M. N. (1978). Plant growth promoting rhizobacteria on radishes. Proceedings of the International Conference on Plant Pathogenic Bacteria, Angers, Anjou, France, 4. 
Kokalis-Burelle, N., Kloepper, J. W., \& Reddy, M. S. (2006). Plant growth promoting rhizobacteria as transplant amendments and their effects on indigenous microorganisms. Applied Soil Ecology, 31(1-2), 91-100. doi: 10.1016/j. apsoil.2005.03.007

Ministério da Agricultura, Pecuária e Abastecimento (2009). Regras para análises de sementes. Brasília. MAPA.

Matoso, E. S., Avancini, A. R., Maciel, K. F. K., Alves M. C., Simon, E. D. T., Silva, M. T. da.,... Silva, S. D. dos A. (2020). Use of a mix of diazotrophic bacteria on the biometrics and chlorophyll content of sugarcane plants. Brazilian Journal of Development, 6(2), 7261-7274. doi: 10.34117/ bjdv6n2-141 117/ bjdv6n2-141

Moreira, F. M. S., Silva, K., Nóbrega, R. S. A., \& Carvalho, F. (2010). Bactérias diazotróficas associativas: diversidade, ecologia e potencial de aplicações. Comunicata Scientiae, 1(2), 74-99.

Nascente, A. S., Filippi, M. C. de, Lanna, A. C., Souza, A. C. de, Silva Lobo, V. L. de, \& Silva, G. B. da (2017). Biomass, gas exchange, and nutrient contents in upland rice plants affected by application forms of microorganism growth promoters. Environmental Science and Pollution Research, 24(3), 2956-2965. doi: 10.1007/ s11356-016-8013-2
Saharan, B. S. (2011). Plant growth promoting rhizobacteria: a critical review. Life Sciences and Medicine Research, 21(1), 1-30. Recovered from https:// astonjournals.com/manuscripts/Vol2011/ LSMR-21_Vol 2011.pdf

Sousa, I. M., Nascente, A. S., \& Filippi, M. C. C. de. (2019). Bactérias promotoras do crescimento radicular em plântulas de dois cultivares de arroz irrigado por inundação. Colloquium Agrariae, 15(2), 140-145. doi: 10.5747/ca.2019.v15.n1.a293

Sperandio, E. M., Vale, H. M. M., Reis, M. S., Cortes, M. V. C. B., Lanna, A. C., \& Filippi, M. C. C. de. (2017). Evaluation of rhizobacteria in uplant rice in Brazil: growth promotion and interaction of induced defense responses against leaf blast (Magnaporthe oryzae). Acta Physiologiae Plantarum, 39(1), 258270. doi: 10.1007/s11738-017-2547-x 